\title{
ИНФОРМАЦІЙНІ ТЕХНОЛОГІї
}

\section{УДК 61:616-02 \\ ОБГРУНТУВАННЯ ПРИНЦИПІВ ДІЇ ТА ВИЗНАЧЕННЯ ОСНОВНИХ ПАРАМЕТРІВ ДІАГНОСТИЧНО-ОЗДОРОВЧОГО КОМПЛЕКСУ «QUANTON» ОГОРОДНИК І.М., ВИСОЦЬКА О.В., СЛІПЧЕНКО М.І., ТЕРНЮК М.Е.}

Досліджується принцип дії процесів діагностики i оздоровчого впливу та основні параметри діагностично-оздоровчого комплексу «QUANTON». Досліджуються також методи неінвазивної діагностики та оздоровчого впливу на організм 3 використанням електромагнітних явищ. Встановлюється, що ефективними фізичними принципами дії для отримання переробки інформації при виконанні процесів діагностики є проява особливостей стану органів і систем на їх спектральних характеристиках, а також ефект зміни імпедансу шкіри при реакції організму на інформаційні маркери.

Ключові слова: комплекс «Quanton», неінвазивна діагностика, спектральний метод, бінарний метод, частотна терапія, оздоровчий вплив.

\section{1. Вступ}

Методи швидкої неінвазивної діагностики та безмедикаментозного відновлення функціонально-фізіологічного стану людей набувають в останній час все більшої популярності. Це пов'язано 3 тим, що такі методи мають суттєві переваги, які полягають у оперативності дії, відсутності побічних ефектів та можливості їх застосування поза медичними закладами.

Для реалізації зазначених методів можуть застосовуватись діагностично-оздоровчі комплекси, що мають різні функціональні можливості, різні рівні технізації та використовують при цьому різні біофізичні ефекти (оптичні, акустичні, магнітні, термічні, ядерно-резонансні, хвильові та інші). Одним 3 таких комплексів $є$ «QUANTON» [1], що поєднує спеціальні спектральний та бінарний методи отримання інформації про стан організму та характеристики потрібного нормалізуючого впливу на нього і реалізує біорезонансний метод оздоровчого впливу. Важливим тут $є$ можливість завчасного визначення стану біосистеми, щоб попередити порушення стабільності гомеостазу під впливом зростаючих ентропійних процесів.

Разом $з$ цим до теперішнього часу в опублікованих роботах та практичній діяльності невідомий метод обгрунтування принципів дії цього комплексу на етапах діагностики i оздоровчого впливу. Особливо це стосується забезпечення заданого рівня достовірності, продуктивності та ефективності процесів, визначення його основ- них конструктивних, технологічних і експлуатаційних параметрів. Це не дозволяє виконувати структурно-параметричну оптимізацію комплекcy.

У той же час виявлені фундаментальні закономірності реакцій організму людей на певні інформаційні та електрохвильові біорезонансні впливи. Ці закономірності проявляються у вигляді змін значень окремих фізичних та біохімічних параметрів тіла, які можуть бути об'єктивно виміряні та використані для створення ефективних діагностично-оздоровчих комплексів. Тому актуальним є обгрунтування вказаних принципів дії та визначення параметрів комплексу «QUANTON».

\section{2. Об'скт дослідження та його технологічний аудит}

Об'єктом дослідження є принципи дії процесів діагностики i оздоровчого впливу та основні конструктивні, технологічні і експлуатаційні параметри діагностично-оздоровчого комплексу «QUANTON».

\section{3. Мета та задачі дослідження}

Метою дослідження є обгрунтування принципів діï діагностично-оздоровчого комплексу «QUANTON» 3 використанням електромагнітних явищ та визначення його основних конструктивних, технологічних і експлуатаційних параметрів для забезпечення заданого рівня достовірності, продуктивності і ефективності процесів.

Для досягнення поставленої мети треба виконати такі завдання:

3.1. Дослідити існуючі концепції будови та функціонування організму, а також методи неінвазивної діагностики та оздоровчого впливу на нього з використанням електромагнітних явищ.

3.2. Обгрунтувати ефективні фізичні принципи дії для отримання і переробки інформації при виконанні процесів діагностики та оздоровчого впливу.

3.3. Розробити метод та визначити основні параметри комплексу «QUANTON» для забезпечення заданої достовірності діагностики, продуктивності процесів та ефективності оздоровчого впливу.

3.4. Виконати контрольні експерименти для оцінки результативності методу.

\section{4. Методи досліджень}

При дослідженні були використані такі наукові методи:

- визначення умов забезпечення необхідних показників на основі загальних медикобіологічних підходів та ідентифікації типу задачі оптимізації;

- логіко-математичне моделювання показників ефективності та обмежень; 
- вирішення задачі структурної оптимізації шляхом перебору варіантів;

- експериментальне визначення показників станів пацієнтів;

- кількісний аналіз при вивченні міри впливу показників процесу на його результати та при оцінці критерію оптимальності.

5. Дослідження існуючих концепцій будови та функціонування живих біосистем, а також методи неінвазивної діагностики та оздоровчого впливу на організм людини 3 використанням електромагнітних явищ

Протягом багатьох років існували дві основні концепції - теорії щодо функціонування живих організмів. Більш поширеною теорією до сьогоднішнього дня $є$ та, що визначає всі живі організми складеними 3 розрізнених частин, які називаються клітинами і організовані відповідно до фізико-хімічної взаємодії між собою. Цю теорію часто називають клітинною теорією життя. Ї̈ї сучасне походження засноване на роботі Harvey (1578-1657) і Lavoisier (1743-1794), які відповідно застосовували цю теорію для пояснення кровообігу, хімічної природи дихання i обміну речовин. При цьому аналіз базувався на механістичному постулаті, що життя є не більш, ніж складна реакція між розрізненими хімічними або атомними сутностями. Це означає, що живий організм дорівнює сумі його частин.[2]

Менш поширену теорію часто називають віталізмом. Віталізм стверджує, що живий організм більше, ніж сума його атомних складових. Він по суті постулює, що існує неатомна сила, яка діє для організації атомних складових. Ця неатомна сила використовувалася для пояснення сталості форми організмів у часі, незважаючи на поточні хімічні реакції, сталість яких не могла бути пояснена теорією клітин [3].

У 1920-х і 1930-х роках Гарольд С. Берр з Сльської медичної школи і Філмер С. Нортроп 3 Єльської юридичної школи виклали свою теорію, що стосується проблем як механізму, так i віталізму. Їх електродинамічна теорія стверджує, що "структура або організація будь-якої біологічної системи встановлюється складним електродинамічним полем, яке частково визначається його атомно-фізико-хімічними компонентами і частково визначає поведінку і орієнтацію цих компонентів" [4].

Теорія синтезувала клітинні та віталізмові теорії, застосовуючи сучасну релятивістську фізику в біологічних системах, а формула А. Ейнштейна $\mathrm{E}=\mathrm{mc}^{2}$ дозволила зрозуміти зв'язок енергії $\mathrm{i}$ речовини. Речовина (тобто молекулярно-атомний рівень) - це субстанція, яка створюється за рахунок частот вібрації енергіі, тобто це - «за- тверділе» світло в корпускулярному стані на відміну від хвильового (тонкого).

Живий організм - це перш за все енергетична система, де діють ті ж закони термодинаміки, що i в неживій природі. Слід однак врахувати, що живі організми характеризуються деякими особливостями, які відсутні у фізичних об'єктів. Це, як відомо, розмноження, розвиток, саморегуляція. Тому енергетичний обмін таких систем має своєрідні якості, притаманні тільки відкритим динамічним біосистемам [5].

Особливістю біосистем $є$ те, що в них практично немає зворотних процесів. Всі процеси, які в них протікають, мають незворотний характер, тобто супроводжуються збільшенням ентропії. Але, оскільки відкриті біосистеми функціонують за законами нерівноважної термодинаміки, для них існує стаціонарний стан як найбільш впорядкований для відкритої системи, при якій швидкість зростання ентропії мінімальна [6].

Ентропія в біологічних системах під впливом зовнішніх деструктивних факторів, таких, як: сильне електромагнітне випромінювання, геопатогенні, радіаційні та хімічні впливи, стрес тощо, може досягти рівня, при якому порушиться енергетичний баланс в життєво важливих функціях організму. Якщо дисбаланс утримується тривалий час під постійним впливом деструктивного фактора, можуть змінитися потенціали клітинних мембран, що вплине на їх проникність. Можуть також порушитись окислювально-відновні процеси та кислотно-лужна рівновага, що не відповідатиме принципам саморегуляції даної біологічної системи, тобто виникнуть сталі функціональні відхилення [7].

Згідно з принципом Гельфанда-Цетліна, постулюється необхідність максимальної автономності роботи підсистем біологічної системи, при якій остання функціонує оптимально і окремі іï частини мінімально взаємодіють одна $з$ одною. Цей принцип наголошує на необхідності існування зворотного зв'язку, що забезпечує стійкість системи [8]. Організм людини як відкрита енергоінформаційна, термодинамічно нерівноважна система постійно перебуває в квазістабільному стані і легко переходить в інший квазістабільний стан під впливом зовнішніх інформаційнохвильових факторів, що збільшують або зменшують іï ентропію [9]. Будь-які подразники або спеціальні маркери (предмет, слово, образ, символ, музика, текст) можуть викликати зміну внутрішніх енерго-інформаційних процесів, переводячи біосистему в новий квазістабільний стан. Така зміна може відбуватися як за участю когнітивних функцій із залученням органів відчуттів, так і без них. Тіло людини здатне реагувати на введення в його інформаційний простір 
польових або матеріальних структур, що впливають на його ентропійність. Ця здатність дає можливість отримання бінарної інформації (такні, або корисно-шкідливо) від організму людини у вигляді реакції на дотик до різного роду предметів, таких як продукти харчування, трави, медикаменти, хімічні речовини. Крім того, це дає змогу оцінювати якість впливу навколишнього середовища на організм і можливість визначити навантаження організму в цілому та окремих його систем хімічним, радіаційним та стресовим фактором.

Будь-який сигнал, переданий з біологічного джерела, можна назвати біосигналом. Джерело сигналу може бути на молекулярному рівні, на рівні клітин, або на рівні системи чи органу. Приклади використання біосигналів в діагностичних цілях: електрокардіограма (ЕКГ) - електрична активність окремих нейронів чи клітин серця; електроенцефалограма (ЕЕГ) - електрична активність головного мозку; електроміограма (ЕМГ) - електрична активність м'язів. Сучасні технології дозволяють отримувати велику множину каналів цих сигналів [10]. Але названі вище методи не можуть показати причину виявлених функціональних порушень та деструктивних змін в організмі людини. Крім того, вони недоступні для автономного користування у повсякденному житті.

Серед доступних методів функціональної діагностики є метод I. Накатані, метод електропунктури Р.Фолля (EIV) та метод вегетативнорезонансного тесту (ВРТ) Г. Шиммеля.

Метод I. Накатані дозволяє виявляти на тілі людини лінії з підвищеною електропровідністю, так звані "ріодораку", провідність яких залежить від стану органів і систем. Це відкрило принципову можливість перевіряти функціонування організму без проведення хірургічних або інших інвазійних тестів. Метод доступний, простий але не достатньо інформативний, крім того, залежний від досвіду оператора, що суттєво обмежує його використання [11].

Метод Р. Фолля передбачає вимірювання електричного опору шкіри в біологічно активних точках, стан яких залежить від стану відповідного органу. Залежно від запалення, хронічних процесів чи норми в тканинах даного органу буде різний опір шкіри в конкретній точці. Це склало початкову основу багатьох швидких та неінвазійних методів технічного діагнозування 3 реєстрацією параметрів для порівняння і моніторингу в процесі лікування. Головними недоліками методу є потреба виміру багатьох точок на руках i ногах та великого досвіду при вимірюванні та інтерпретації отриманої інформації. Крім того, пацієнт має бути відповідно підготовлений, спокійний, 3 непошкодженою шкірою на пальцях рук і ніг [12].

Метод Г. Шиммеля є більш вдосконаленим. Він базується на реакції організму людини чи тварини на вібраційний або енергетичний вплив матеріальної субстанції, що торкається тіла. При тестуванні використовується тільки одна репрезентативна точка на руці, в якій фіксується зміна імпедансу шкіри на підключений до тіла препарат за принципом: «так - ні». Якщо тіло реагує на препарат зміною імпедансу шкіри, то це означає, що цей препарат має дію на організм, не реагує нейтральний. Тобто відбувається бінарна ідентифікація стану організму $[13,14]$.

Для цього методу створені спеціальні препарати - нозоди, які потім копіювалися у вигляді просторових зарядів до інтегральних електронних схем - постійних запам'ятовуючих пристроїв (ПЗП).

Для зберігання інформації використовується репрограмований постійний запам'ятовуючий пристрій, який будується на основі фізичного явища зберігання заряду на кордоні між двома різними діелектричними середовищами або провідником і діелектриком [15]. Діелектрики, маючи низьку електропровідність, здатні тривалий час зберігати створений в них нерівноважний просторовий розподіл електричного заряду. Формування такого розподілу може здійснюватися різними способами. У сегнетоелектричному діелектрику зарядовий рельєф може бути створений за допомогою формування в кристалі доменної структури із заданим розташуванням заряджених доменних стінок [16].

Вібраційні сигнали органів, клітин, мікроелементів, всіх відомих мікроорганізмів, токсинів i багатьох інших речовин, необхідних для тестування, можна копіювати і зберігати в електронних пристроях. Ці інформаційні одиниці отримали загальну назву «маркер» і складають так званий електронний медичний селектор, який містить понад 30 тис. зразків. Перевіряючи різні маркери, відібрані для тестування за спеціальними алгоритмами, оператор знаходить хворі органи за принципом: є реакція організму на маркер певного органу - в цьому органі $є$ проблема; $\epsilon$ реакція на вірус - вірус $є$ в організмі. Великою перевагою такого підходу є те, що, об'єднуючи різні маркери в певній конфігурації, можна визначити причину виявленої дисфункції в конкретному органі та знайти оптимальний шлях для іiі ліквідації, прогнозуючи при цьому ефективність вибраної терапевтичної дії $[17,18]$.

Суттєвий недолік всіх розглянутих методів суб'єктивізм при тестуванні і необхідність великого досвіду роботи, від якого залежить достовірність отриманої інформації. Все це переш- 
коджає стандартизації методів для використання в широкому колі фахівців медицини.

Більш незалежним від оператора та автоматизованим $є$ метод спектрального аналізу, який базується на сукупності методів якісного і кількісного визначення складу об'єкта, заснований на вивченні спектрів взаємодії матерії 3 випромінюванням, включаючи спектри електромагнітного випромінювання, акустичних хвиль, розподілу по масах і енергій елементарних частинок.

В останні кілька років інтерес розробників діагностичних методів був приділений частотночасовому аналізу, особливо що стосується обробки біологічного сигналу. Фактично, аналіз в частотній області $є$ добре стандартизованим інструментом для кількісної оцінки багатьох клінічних і фізіологічних явищ $[19,20]$.

Частотно-часовий аналіз використовує швидке перетворення Фур'є для розкладання сигналу, отриманого від організму, на його складові, а також оцінку характеристик сигналу - амплітуди, фази, спектральної щільності, потужності та ін. Це дає можливість швидкої оцінки стану організму на основі порівняння його стохастичних характеристик із стохастичними характеристиками відповідних маркерів, що містяться в базі даних [21]. Однак спектральний аналіз не використовує біологічно-зворотний зв'язок для верифікації і корекції отриманих даних, тому ймовірність похибки при отриманні діагностичної інформації є досить високою.

\section{6. Результати дослідження}

6.1. Обгрунтування ефективних фізичних принципів дії для отримання і переробки інформації при виконанні процесів діагностики та оздоровчого впливу. При обгрунтуванні ефективних принципів дії для отримання і переробки інформації ставиться задача синтезувати послідовність вимірювальних операцій, які б за короткий час, неінвазивно, в автоматичному режимі дозволяли отримати інформацію про стан основних систем і органів людини та визначити характеристики режимів оздоровчого електрохвильового впливу. При цьому треба врахувати наявні обмеження, згідно з якими:

- виконуються умови електричної безпеки;

- не допускається отримання побічних шкідливих впливів;

- рівень достовірності результату діагностики повинен бути не нижчим заданого;

- процеси діагностики та оздоровчого впливу повинні бути максимально продуктивними;

- оздоровчий вплив має бути максимально ефективним;

- комплекс повинен бути як стаціонарним, так i переносним;
- комплекс повинен мати модульну будову.

Виходячи iз перших чотирьох умов, можна зазначити, що метод неінвазивної комплексної діагностики повинен поєднувати спектральний та бінарний методи отримання інформації про стан організму та визначати характеристики потрібного нормалізуючого впливу на біологічний об'єкт [22]. Спектральна діагностика дозволяє визначити проблемні органи та системи, а бінарна, за допомогою біологічно-зворотного зв'язку - зверифікувати і конкретизувати діагностичну інформацію. При цьому $є$ можливість керувати рівнем достовірності процесів.

Вегетативна нервова система, керована лімбічною системою, має здатність реагувати на різні сенсорні стимули довготривалими реакціями (до 12 с). Це створює можливість використання імпедансу для відслідковування реакції біосистеми на сенсорний (тактильний, візуальний, акустичний) зовнішній вплив та побудови відповідного автоматизованого комплексу.

На етапі діагнозування метод може реалізуватись 3 допомогою багатоканального комплексу 3 рівнем технізації, який зменшує до прийнятного мінімуму залежність цього процесу від досвіду оператора. Для цього потрібно автоматизувати бінарний спосіб отримання фіксованих реакцій організму на дію маркера шляхом створення багатоконтактного сенсора, який подає на автоматизований пристрій сигнал про зміну характеристик тіла. Таке доопрацювання дозволить збільшити продуктивність, а автоматизована обробка отриманої різними шляхами діагностичної інформації - довести достовірність діагнозування до потрібного рівня.

На етапі виконання оздоровчого впливу на основі значної кількості експериментів виявлено, що найбільш ефективним $є$ застосування сигналу спеціальної форми, частота якого є індивідуальною для даної людини на даний момент і лежить в діапазоні дециметрових або міліметрових хвиль. При цьому амплітуда не повинна перевищувати 5 вольт.

Особливістю методу «QUANTON» $є$ те, що при застосуванні бінарного процесу діагностики, на основі біологічно-зворотного зв'язку, є можливість визначати найбільш результативні i ефективні параметри оздоровчого впливу шляхом запиту організму про їх значення за допомогою інформаційних маркерів.

6.2. Розробка методу та визначення основних параметрів комплексу «QUANTON» для забезпечення заданої достовірності діагностики, продуктивності процесів та ефективності оздоровчого впливу. Виходячи 3 вказаного, можна ідентифікувати тип задачі пошуку потрібних рішень: це задача комплексної структурно- 
параметричної оптимізації системи 3 векторним критерієм оптимальності.

Необхідність структурної оптимізації зумовлює доцільність застосування для їі вирішення методу послідовного перебору впорядкованої області структур iз наступним аналітичним аудитом знайдених рішень [23]. Аудит потрібний для можливого покращення попередньо вибраного рішення у зв'язку з множинністю варіантів загального критерію оцінки системи.

Спектральний i бінарний методи допускають повтори. У зв'язку з цим модель загального рівня $P_{z}$ достовірності отриманої інформації в процесі діагнозування можна представити 3 врахуванням повторів $n$ та $m$ разів, відповідно спектрального та бінарного замірів, наступною залежністю [24]:

$$
P_{z}=1-q_{s}^{n} \cdot q_{b}^{m}
$$

де $q_{s}, q_{b}$ - ймовірності похибок при отриманні інформації 3 двох незалежних каналів: спектрального та бінарного відповідно.

Умовою забезпечення потрібного рівня $P_{z}$ достовірності діагностики є:

$$
P_{z} \geq\left[P_{z}\right]^{-}
$$

де $\left[P_{z}\right]$ - мінімально допустиме значення $P_{z}$.

Із залежності (1) випливає, що при постійних значеннях ймовірностей похибок при отриманні інформації забезпечити потрібне значення $P_{z}$ можливо за рахунок вибору $n$ та $m$ відповідно, тобто у загальному випадку необхідний перехід від разового виміру до множини вимірів 3 певними значеннями їх повторень. При цьому слід враховувати, що величини $n$ та $m$ порізному впливають на продуктивність процесу діагнозування i значення $P_{z}$ : при збільшенні $n(m)$ продуктивність падає, а рівень достовірності зростає.

При реалізації методу «QUANTON» операції на двох незалежних каналах (спектральному та бінарному) виконуються послідовно, результати першої $\epsilon$ умовою початку роботи другої. Цей метод може бути розширений, наприклад, за рахунок використання додаткового каналу зняття інформації (іридо-, тепловізійного або іншого), що добавить множник у залежності (1). Забезпечуючи перехід від однієї точки виміру до множини точок, при бінарній діагностиці також можна зменшувати $q_{b}$.

Визначивши показник продуктивності як критерій оптимізації і критерій оптимальності, для кожної структурної конфігурації комплексу постановку задачі параметричної оптимізації можна записати так:
- критерій:

$$
t_{z}=t_{p z s}+t_{s}^{n}+t_{p z b}+t_{b}^{m} \rightarrow \min ,
$$

- обмеження:

$$
\left(1-q_{s}^{n} q_{b}^{m}\right) \geq\left[P_{z}\right]
$$

$n \geq 1 ; \quad 4 \geq m \geq 1 ; \quad 5 \geq V \geq 1$,

де $t$ - час; нижні індекси $p z$ означають підготовчо-заключний час; $s$ та $b$ - відношення параметра до операцій спектральної та бінарної діагностики відповідно; $t_{s}, t_{b}$ - основний (машинний) час на вказаних операціях.

Число 4 означає, що кількість повторень замірів на одній біологічно-активній зоні не повинна перевищувати 4-х. При потребі, у подальшому замір може проводитись по інших зонах.

Обмеження (4) формують блокуючий контур, у межах якого знаходиться оптимальне по критерію продуктивності рішення.

Виходячи 3 залежностей (3), (4), можна зробити висновок, що процес діагностики, який складається 3 двох операцій і оптимізується по критерію продуктивності, має досить широкі можливості впливу на рівень достовірності його результатів діагностики. Цей рівень забезпечується, у першу чергу, наявністю повторних вимірів. Наприклад, при заданому нормативному рівні $\left[P_{z}\right]=0,99$ та при реальних досить широких значеннях $q_{s}=q_{b}=0,1$ умова (2) виконується при $n=m=1 \quad\left(P_{z}=10,1 \cdot 0,1=0,99\right) . \quad$ 3більшення, наприклад, $m$ до 2-х за рахунок повторення вимірів при $q_{b}=0,1$ зменшує загальну похибку у 10 разів [25]

Враховуючи сумарний симетричний вплив добутку параметрів у степенях $n$ та $m$ на $\left[P_{z}\right]$, можна встановити, що при збільшенні одного 3 них є можливість зменшити другий.

Очевидно, що за допомогою залежностей (3), (4) можна виконувати аналіз придатності різних технічних засобів, які використовуються при спектральній та бінарній діагностиці, як по рівню достовірності діагностики, так і по рівню продуктивності процесу. Наприклад, перехід від ручного контактування електроду 3 біологічно активною точкою до автоматизованого забезпечує скорочення часу діагностики в 20 і більше разів.

Оптимальним по критерію продуктивності $\epsilon$ рішення, при якому мінімальну кількість повторень замірів має та операція, у якої довший основний (машинний) час іiі виконання.

У разі невиконання обмежень (4) потрібно вводити додатковий канал отримання інформації. При оптимізації по критерію продуктивності час виконання діагностики на цьому каналі повинен 
збігатися з часом проведення однієї із вказаних раніше операцій - спектральної та бінарної діагностики.

База інформаційно-хвильових чи частотних маркерів, що закладена в діагностичному модулі комплексу, застосовується в певній конфігурації за спеціальним алгоритмом. Застосовуючи цей алгоритм при подачі сигналів-запитів, визначають параметри потрібного, найбільш оптимального за ефективністю впливу (частота, тривалість їх подачі та кількість повторів сеансів).

На основі даних, отриманих від організму, створюється індивідуальна коригуюча програма для декількох патологічних процесів одночасно i програмується нею спеціальний терапевтичний автоматизований модуль, який забезпечує потрібну оздоровчу процедуру.

Аналітичний аудит використовується 3 метою пошуку, наприклад, енергоефективних рішень, що потрібно для забезпечення тривалої дії без додаткової зарядки джерел енергії переносного (мобільного) обладнання.

\section{3. Експериментальне визначення результа- тивності методу «QUANTON»}

Результативність методу «QUANTON» підтверджена позитивними результатами його застосування при оздоровленні понад 3-х тисяч людей.

Нижче наведені два типові приклади застосування методу «QUANTON», які дають інформацію про його результативність.

Дослідження проведені з використанням апаратно-програмного комплексу „Ольвія Нова” (м. Київ), а корекцію фізіологічних процесів за допомогою методу «QUANTON», реалізованого на базі спеціального обладнання „Quanton A2”, виготовленого в США. Контрольні методи вимірювання проводились за допомогою мікроскопу та приладу неінвазійного аналізу крові „АМП” («Біопромінь», м. Харків).

Приклад 1. Пацієнт 13 низкою симптомів: хронічна втома, патологічна сонливість аж до засинання за кермом на червоному світлі світлофора, вірусний гепатит $\mathrm{B}$, що супроводжувався болями в правому підребер'ї, проблеми 3 травленням і висипаннями на шкірі.

На рис. 1 наведені фотографії гемосканування краплі крові пацієнта 1 до застосування методу.

На рис. 2 показано стан крові цього пацієнта після 5-денної дії індивідуальних частотних програм, визначених по методу «QUANTON».
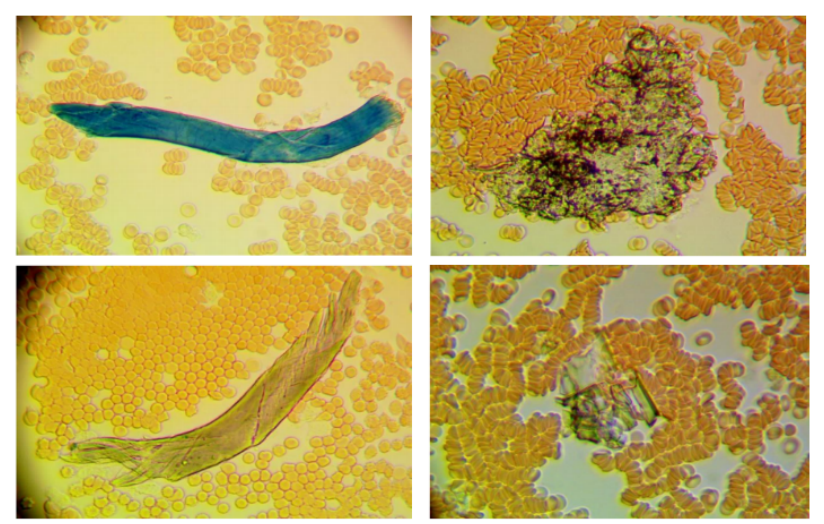

Рис. 1. Гемосканування краплі крові перед дією терапевтичної програми
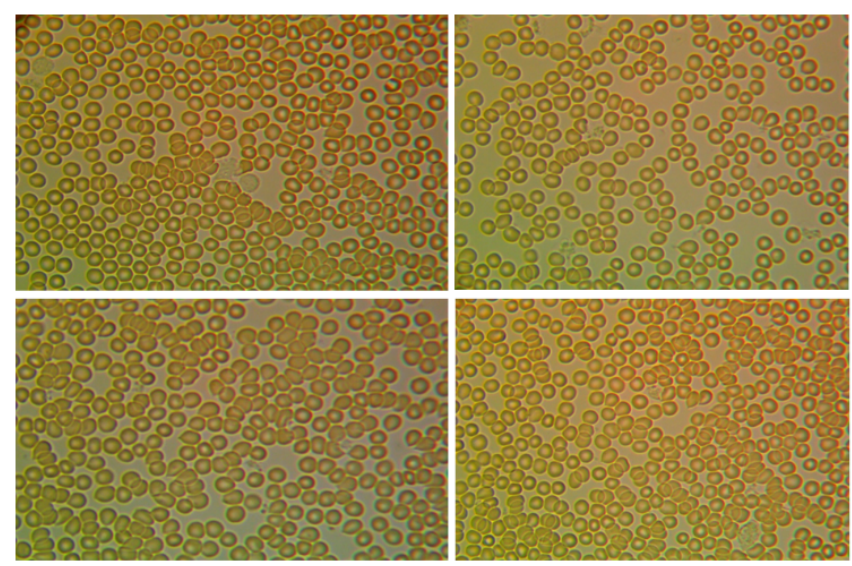

Рис. 2. Стан крові після 5-денної терапії методом «QUANTON»

Як видно на знімках, відбулося повне відновлення мембранних потенціалів еритроцитів, зниження яких призвело до "злипання" їх між собою. Розчинилися всі сторонні речовини, такі як холестерин, кристали сечової кислоти, різного роду симпласти.

При цьому стан пацієнта 1 істотно покращився: пройшла сонливість, стабілізувалось травлення i найважливіше - після здачі чергових аналізів за місцем проживання вдвічі знизилася реакція організму на гепатовірус.

Приклад 2. У пацієнта 2 були тривалі тупі болі у правому боці, що супроводжувались частими здуттями та дисфункцією органів травлення. При проведенні тесту вегето-резонансним методом виявилась наявність у печінці трематод: Fasciola hepatica i Clonorchis sinensis. Тестувались також запальні стани печінки та дисфункція жовчних шляхів. В день тестування (10.02.2018) було проведено неінвазійний аналіз крові, який підтвердив запальний стан в печінці з різким підвищенням загального і непрямого білірубіну, а також дуже високий рівень аланінамінотрансферази 
(ALT), концентрація в крові якої різко підвищується при запальних процесах печінки.

В таблиці 1 представлено витяг з аналізу крові Пацієнта 2 перед початком терапії методом Quanton, на другий день після неї і контрольний вимір через місяць.

Була проведена терапевтична процедура індивідуальними частотними програмами методом Quanton двома сеансами по 14 і 10 годин відповідно. Після цього на наступний день (11.02.2018) зроблено контрольний тест, який показав, що всі параметри які характеризують стан печінки, прийшли до норми, а стан пацієнта істотно покращився. Контрольна перевірка крові методом АМП через місяць (11.03.2018) показала стабільність показників печінкових проб. Таким чином, проведена 1,5 денна коригуюча програма методом Quanton показала позитивні зміни в загальному стані та на конкретних параметрах.

Пацієнт 2

\section{Печінкові проби:}

№: Показник: Норма: 10.02 .2018 11.02.2018 11.03 .2018

\begin{tabular}{|c|c|c|c|c|c|c|}
\hline 48 & 22 & AST. $\mathrm{mmol} / \mathrm{l}$ & $0,1-0,45$ & 1,23 & 0,32 & 0,32 \\
\hline 49 & 23 & ALT. $\mathrm{mmol} / \mathrm{l}$ & $0,1-0,68$ & 2,58 & 0,33 & 0,33 \\
\hline 50 & 24 & AST. U/1 & $8-40$ & 55,25 & 16,59 & 15,85 \\
\hline 51 & 25 & ALT. U/1 & $5-30$ & 116,12 & 17,08 & 16,26 \\
\hline 52 & 26 & AST/ALT & $0,8-1,2$ & 0,48 & 0,97 & 0,97 \\
\hline 53 & 27 & $\begin{array}{l}\text { Білірубін } \\
\text { загальний. } \\
\mu \text { mol/1 }\end{array}$ & $8,6-20,5$ & 46,24 & 12,29 & 12,29 \\
\hline 54 & 28 & $\begin{array}{l}\text { Білірубін } \\
\text { прямий. } \\
\mu \mathrm{mol} / 1\end{array}$ & $2,2-6,1$ & 10,61 & 3,03 & 3,37 \\
\hline 55 & 29 & $\begin{array}{l}\text { Білірубін } \\
\text { непрямий. } \\
\mu \mathrm{mol} / 1\end{array}$ & $1,7-10,2$ & 35,62 & 9,25 & 8,93 \\
\hline
\end{tabular}

Зазначені результати досягнуті при застосуванні електромагнітного впливу індивідуально визначених частот в дециметровому та міліметровому діапазонах хвиль під конкретні проблеми в даний момент часу. Визначення відповідної частоти в потрібний момент дозволяє реалізувати ефект синхронізації біологічних процесів і ритмів організму з дією терапевтичного обладнання, щоб отримати максимальний терапевтичний ефект, використовуючи внутрішні механізми саморегуляції. Організм пацієнта при цьому отримує додаткову енергію від впорядкування фізіологічних процесів.

\section{SWOT-аналіз результатів досліджень}

Strengths. Використання електромагнітних явищ у біофізичних процесах та біохімічних реакціях живих біосистем надає можливість створення індивідуального діагностично-оздоровчого ком- плексу. Цей комплекс на підставі зібраної з організму різними каналами інформації зможе проводити аналіз і видавати рекомендації по фізіологічній корекції та відновленню нормального гомеостазу і балансу енергетики органів.

Постановка i вирішення задачі параметричної оптимізації принципів дії діагностичнооздоровчого комплексу «QUANTON» дають можливість забезпечувати потрібний (нормативний) рівень достовірності результатів діагностики, обрані безпосередньо організмом параметри оздоровчого впливу при максимальній продуктивності процесу. Наявна можливість побудови персональних (мобільних) смарт-діагностичнооздоровчих апаратних комплексів з високим рівнем їх функціональних можливостей.

Weaknesses. Слабкою стороною наявних діагностично-оздоровчих апаратних комплексів є значна залежність результатів діагностики від їх конструктивних особливостей.

Opportunities. У подальшому доцільною $є$ розробка повністю автоматизованих (з використанням елементів штучного інтелекту) смартдіагностично-оздоровчих апаратних комплексів. Це суттєво збільшить сферу їх застосування завдяки переміщенню процесу діагностики та оздоровлення із спеціалізованих центрів у персональний побут, що важливо для усіх країн світу.

Threats. Складність впровадження результатів дослідження полягає у потребі первинних капіталовкладень у підготовку виробництва діагностично-оздоровчих апаратних комплексів. Однак на сучасних спеціалізованих гнучких виробництвах капітальні витрати можуть мінімізуватись.

\section{8. Висновки}

1. Існуючі концепції будови та функціонування організму створюють достатню наукову базу для розробки ефективних методів неінвазивної діагностики та оздоровчого впливу на нього 3 використанням електромагнітних явищ.

2. Ефективними фізичними принципами дії для отримання і переробки інформації при виконанні процесів діагностики $\epsilon$ проява особливостей стану органів і систем на їх спектральних характеристиках, а також ефект зміни імпедансу шкіри при реакції організму на інформаційні маркери.

Спільне використання цих методів дозволяе забезпечити заданий рівень достовірності при вищій продуктивності процесів.

Оздоровчий вплив на організм людини може бути електро-хвильовим з частотами, тривалістю і кількістю сеансів, які визначені безпосередньо самим організмом при бінарній діагностиці у режимі «он-лайн».

3. Методом забезпечення вищої ефективності комплексу «QUANTON» за показниками про- 
дуктивності процесів 3 одночасним виконанням обмежень (на рівень достовірності, безпеки та інші) $€$ метод комплексної структурнопараметричної оптимізації.

Основними структурно-параметричними характеристиками комплексу «QUANTON», що забезпечують його ефективне функціонування, $є$ :

- конструктивні: наявність двох каналів діагностики (спектральний та бінарний), модульність, програмованість;

- технологічні: можливість визначення характеристик оздоровчого впливу безпосередньо самим організмом людини; застосування індивідуальних частот в діапазоні дециметрових і міліметрових хвиль; кількість можливих повторів вимірів та здійснення оздоровчих впливів не обмежена; - експлуатаційні: стаціонарний та переносний варіанти; здатність до забезпечення максимальної продуктивності, можливість забезпечення рівня достовірності до 0,999 і вище.

4. Виконані експерименти для оцінки результативності методу та багатолітня практика його застосування при оздоровленні понад 3-х тисяч людей показали можливість ефективного оздоровлення при різноманітних вірусних та соматичних хворобах, у тому числі - хворобах крові, мігренях, гепатитах та багатьох інших.

\section{Література:}

1. Ogorodnyk I., Vysotska O., Ternyuk M., Bilovol H. Development of the method of structural and parametric synthesis of the quanton diagnostic and health complex. Eastern-European Journal of Enterprise Technologies $\begin{array}{lllll}\text { ISSN } & 1729-3774 & 4 / 9 & \text { (100) } & 2019 .\end{array}$ DOI: https://doi.org/10.15587/1729-4061.2019.176174

2. Jackson J. Spielvogel, WESTERN CIVILIZATION, Eighth Edition, The Pennsylvania State University. 2012. $562 \mathrm{p}$.

3. Elizabeth Ann Williams. A Cultural History of Medical Vitalism in Enlightenment Montpellier. Ashgate, 2003.

4. Burr, H. S. and F. S. C. Northrop. The ElectroDynamic Theory of Life. Quarterly Revue of Biology. 1935. Vol. 10. P. 322-333.

5. Рубин А.Б. Термодинамика биологических процессов. М.: Изд-во МГУ, 1984. 283 с.

6. Луцеенко Н.Г. Начала биохимии. Курс лекций / РХТУ им. Д.И. Менделеева. М.: МАИК "Наука/итерперводика", 2002, 125 с.

7. Опритов B.A. Энтропия биосистем БИОЛОГИЯ, Нижегородский государственный университет им. Н.И. Лобачевского, 1999.

8. Новиков Д.А. Закономерности итеративного научения. М.: Институт проблем управления РАН, 1998. 77 c. URL: https://texts.news/filosofiyafundamentalnaya/zakonomernosti-iterativnogonaucheniya.html

9. Тимофеев А.Б., Тимофеев Г.А., Фаустова Е.Е., Федорова В.Н. Механические колебания и резонансы в организме человека. Ozon.ru. 2008.
10. Jit Muthuswamy. Biomedical Signal Analysis, Department of Bioengineering, Arizona State University, Tempe, Arizona, Copyright (C) 2004 The McGraw-Hill Companies.

11. Yoshio Nakatani, Tetsuo Oiso. A Guide for Application of Ryodoraku Autonomous Nerve Regulatory Therapy, Official Journal of International Association of Ryodoraku Medical Science. Vol. 1. 2018. P. 1 - 20.

12. Gerda Rondé. Dr. Reinhold Voll: 1909 - 1989, Arzt, Forscher, Lehrer; Elektroakupunktur nach Voll - ein ganzheitliches Diagnose- und Therapiesystem. Med.Literarische Verlag-Ges., 1998.

13. VEGA Testing. Da Vinci. Natural Health Center in Cyprus. URLhttps://www.naturaltherapycenter.com/vegatesting/

14. Elektroacupuncture. Willkommen in der Kessler Praxis. URL: https://www.dr-kessler.net/diagnostics-andtherapies/elektroacupuncture-vega-test/

15. Wolf, F.A. Taking the Quantum Leap. New York, Harper and Row, 1981. Pp.65-66.

16. Lampert M.A., Mark P. Current injection in solids. Academic Press. N.Y. London. 1970.

17. Паламарчук М.И., Егорова Т.Ю. Электропунктурный Вегетативный Резонансный Тест - Новые Возможности Диагностики // Оригинальные Исследования. Журнал ГРГМУ 2006 №1. URL: https://cyberleninka.ru/article/v/elektropunkturnyy-

vegetativnyy-rezonansnyy-test-novye-vozmozhnosti-

diagnostiki

18. Vegatest Expert Device. London Centre For Integrative Complementary Medicine And Vegatesting.

URL: https://www.vegatest.info/vegatesting

19. Anna M. Bianchi, Luca T. Mainardi and Sergio Cerutti. Time-frequency analysis of biomedical signals, The Institute of Measurement and Control, 2000.

20. Hualou Liang, Joseph D. Bronzino, Donald $R$. Peterson. Biosignal Processing: Principles and Practices, CRC Press, 2013 by Taylor \& Francis Group.

21. Способ идентификации спектральных характеристик биологических и неживых объектов и их коррекции: деклараційний патент України на корисну модель № 23476 опубл. 25.05.2007.

22. Спосіб відновлення функціональнофізіологічного стану людини: патент України на корисну модель № 128776, опубл. 10.10.2018.

23. Тернюк Н.Э. Законы развития техники и их применение при создании инноваций / Сучасні проблеми науки та освіти: матеріали 16-ї Міжнародної міждисциплінарної науково-практичної конференції 30 квітня - 9 травня 2011. Свпаторія-Харків, «Українська асоціація «Жінки в науці та освіті». Харківський нац. ун-т ім. В.Н. Каразіна. 2012. С. 74-86.

24. Гаврюшов М.A. Структурно-параметрическая оптимизация системы унифицированных технологических элементов / М.А. Гаврюшов // Повышение эффективности технологических процессов в гибком автоматизированном производстве: межвуз. науч. сб. Саратов, 1991. С. 40-45.

25. Ogorodnyk I. Ensuring a specified reliability level of complex spectral-binary diagnostics by the «quanton» method. ISSN 2226-3780 Technology audit and production reserves. № $2 / 2(46), 2019$. c. $32-36$ DOI: $10.15587 / 2312-8372.2019 .169630$ 
Надійшла до редколегії 11.09.2019

Рецензент: д-р фіз.-мат. наук, проф. Панченко О.Ю. Огородник Ігор Миколайович, інженер-винахідник, завідувач відділу Міжнародної академії наук і інноваційних технологій. Адреса: Україна, 03194, Київ, Святошинський район, бульвар Кольцова, 14-Е.

Висоцька Олена Володимирівна, д-р техн. наук, завідувач кафедри 502 Харківського національного аерокомічного університету ім. М.Є.Жуковського. Адреса: Україна, 61070, Харків, вул. Чкалова, 17, радіокорпус, ауд. 221.

Сліпченко Микола Іванович, д-р фіз.-мат. наук, проф. Інститута сцинциляційних матеріалів НАН України. Наукові інтереси: мікрохвільова мікроскопія, мікро- та оптоелектроніка, НВЧ-гігрометрія, приладобудування. Адреса: Україна, 61000, Харків, пр. Науки, 60.

Тернюк Микола Емануілович, д-р техн. наук, професор, президент Міжнародної академії наук та інноваційних технологій. Адреса: Україна, 03194, Київ, Святошинський район, бульвар Кольцова, 14-Е.
Ogorodnyk Igor Mykolayovych, engineer-inventor, head of department, International Academy of Sciences and Innovative Technologies. Address: Ukraine, 03194, Kyiv, Sviatoshynskyi district, Koltsova boulevard, 14-E.

Vysotska Olena Volodymyrivna, Dr. Tech. Sciences, Head of Department 502, Kharkiv National Aerocomic University. ME Zhukovsky. Address: Ukraine, 61070, Kharkiv, street Chkalova, 17, radio building, room 221.

Slipchenko Nikolay Ivanovich, Doctor of Physical and Mathematical Sciences, Professor, Institute for Scintillation Materials NAS of Ukraine. Scientific interests: electrodynamics. Address: 60, Nauky Ave., Kharkiv, 61000, Ukraine.

Ternyuk Mykola Emanuilovych, Dr. Tech. Sciences, Professor, President of the International Academy of Sciences and Innovative Technologies. Address: Ukraine, 03194, Kyiv, Sviatoshynskyi district, Koltsova boulevard, 14-E. 